\title{
EKSISTENSI KEWENANGAN BALAI HARTA PENINGGALAN ATAS ORANG YANG DINYATAKAN TIDAK HADIR (AFWEZIGHEID)
}

\author{
Anindya Bidasari ${ }^{1}$ \\ Email: 899anindya@gmail.com
}

\begin{abstract}
Inherited Property Board in Indonesia until now the existence of authority if not viewed by the public. As the government agency within the Ministry of Justice and Human Rights of the Republic of Indonesia, the Civil Directorate, one of the tasks BHP is to represent the interests of those who are not present and difficult to find or in legal terms is called afwezigheid was instrumental in carrying out the maintenance and management of the property that the owner is declared absent or difficult to find. In determining the absence that can be simultaneously appointed BHP locals who will be in charge of and which represent and defend all the interests of the absentee that during his absence, but without prejudice to the authority of a judge to appoint one or more of the family by blood or marriage of the absentee or to the wife or husband for that purpose (Article 463 paragraph (3) of the Civil Code). This research is legal (normative). The approach will be used in this legal research involved the Statute Approach (approach legislation) and Conceptual Approach (Approach Concept). The results of this study indicate that during this Hall Heritage memili existence of duties and authority as pengampu on people who were not present, the process of absence, there are three stages: (a) The decision of provisional measures, (b) The allegation of law may have died, (c) future Inheritance derivatives, and supported by the District Court case that there is Decision No. 15 / Pdt.P / 2014 / PN.Kdi's absence in inheritance. In line with this Court decision the judge should also assign tasks to BHP as pengampu on people who otherwise may not be present. Because BHP like lawyers resolve the legal issues in the field of assets and management of property from a person who declared no existence hadir.Namun operation of BHP still needed a strong mastery of the Civil Code as well as the community's understanding of BHP.
\end{abstract}

Keywords: Existence, Inherited Property Board, Absentia (afwezigheid).

\section{Pendahuluan}

Seiring dengan perkembangan dan kebutuhan hukum di masyarakat, keberadaan dan eksistensi Lembaga Balai Harta Peninggalan (BHP) mutlak diperlukan dan diharapkan mampu menjawab segala tantangan dalam pembangunanbidang hukum. Kebijakan pembentukan hukum dewasa ini diarahkan untuk membentuk substansi hukum yang responsif dan mampu menjadi sarana pembaharuan dan pembangunan

\footnotetext{
${ }^{1}$ Penulis adalah Dosen Fakultas Hukum Universitas Kanjuruhan Malang
} 
yang mengabdi pada kepentingan nasional dengan mewujudkan ketertiban, legitimasi dan keadilan.

Balai Harta Peninggalan yang berlaku di Indonesia merupakakan unit pelaksana teknis di lingkungan Kementerian Hukum dan Hak Asasi Manusia, secara teknis bertanggungjawab langsung kepada Direktur Jenderal Administrasi Hukum Umum melalui Direktur Perdata, meski semuanya tetap berada dalam naungan Kantor Wilayah Kementerian Hukum dan HAM RI. ${ }^{2}$ Tujuan pendirian Balai Harta Peninggalan (BHP) awalnya untuk memenuhi kebutuhan orang-orang VOC yaitu mengurus harta kekayaan yang ditinggalkan oleh mereka bagi kepentingan para ahli waris yang berada di Nederland, anak-anak yatim piatu dan sebagainya. Oleh karena itu pada era Orde Baru, BHP mengalami pasang-surut karena dianggap sebagai instansi peninggalan Belanda dan diskriminatif (melayani warga Negara/ golongan tertentu). Sampai saat ini di Indonesia hanya ada lima Balai Harta Peninggalan yaitu di Jakarta, Semarang, Surabaya, Medan dan Ujung Pandang. ${ }^{3}$ Khusus wilayah kerja Balai Harta Peninggalan Surabaya meliputi 4 propinsi yaitu: Jawa Timur, Kalimantan Selatan, Kalimantan Timur, dan Kalimantan Tengah.

Pada hakekatnya BHP sebagai instansi Pemerintah di lingkungan Departemen Hukum dan Hak Asasi Manusia Republik Indonesia, Direktorat Perdata, salah satu tugasnya adalah mewakili kepentingan mereka yang tak hadir dan sukar dicari atau dalam istilah hukum disebut afwezigheid sangat berperan dalam melaksanakan pengurusan serta pengelolaan terhadap harta kekayaan yang pemiliknya dinyatakan tak hadir atau sukar dicari. ${ }^{4}$

Balai Harta Peninggalan dalam proses pengurusan terhadap harta kekayaan yang dinyatakan afwezigheid menghadapi berbagai kendala baik secara intern maupun ekstern. Bagi subjek hukum manusia ini menurut hukum dinyatakan dan selanjutnya hanya dapat dibuktikan keberadaan atau eksistensinya dengan penetapan (beschikking) hakim dalam Pengadilan. Dalam penetapan ketidakhadiran itu dapat sekaligus ditunjuk BHP setempat yang akan bertugas mengurus dan yang mewakili serta membela segala

\footnotetext{
${ }^{2}$ www.nurhendroputranto.com.htm, "Balai Harta Peninggalan", diakses tanggal 8 November 2016.

3 Panduan Praktis, Balai Harta Peninggalan Surabaya Fungsi dan Tugas Pokoknya, Kantor Wilayah Kementerian Hukum dan HAM Propinsi Jawa Timur.
} 
kepentingan si tak hadir itu selama ketidakhadirannya, akan tetapi dengan tidak mengurangi kewenangan hakim untuk menunjuk seorang atau lebih dari keluarga sedarah atau semenda dari si yang tak hadir atau kepada isteri atau suaminya untuk keperluan itu (Pasal 463 ayat (3) KUHPerdata). Selanjutnya setelah penetapan tentang ketidakhadiran itu telah memperoleh kekuatan hukum yang tetap (in kracht van gewijsde), maka pengurus atau wakilnya akan melaksanakan segala tindakan pengurusan (daad van beheer) maupun tindakan pemilikan (daad van beschikking) bila perlu sesuai dengan kepentingan boedel afwezig atau kekayaan tak hadir dimaksud.

Contohnya, pada Putusan Pengadilan Negeri Nomor 15/Pdt.P/2014/PN.Kdi, terdapat kasus yang menyatakan bahwa SM sudah menikah dan memiliki seorang anak, dia mendapat warisan dari orang tuanya, dan sejak tahun 2000 SM meninggalkan kediamannya, tanpa memberikan kuasa kepada orang lain untuk mewakilinya atau mengurus kepentingannya, yang mana hal tersebut dapat diketahui dari keterangan saksi bahwa ada tagihan pajak terhadap SM yang tidak terbayar dan Pemohon beserta ahli waris mengalami kesulitan untuk balik nama warisan karena ketidak hadiran SM.

Sejalan dengan Putusan Pengadilan ini seharusnya hakim juga memberikan tugas kepada BHP sebagai pengampu atas orang yang dinyatakan tidak hadir. Karena BHP ibarat pengacara menyelesaikan permasalahan hukum dibidang Harta Kekayaan serta pengelolaan harta dari orang yang dinyatakan tidak hadir.Namun eksistensi bekerjanya BHP masih diperlukan penguasaan Hukum Perdata yang kuat.

Berdasarkan latar belakang dikemukakan diatas, maka yang menjadi permasalahan dalam penulisan ini adalah bagaimana eksistensi kewenangan balai harta peninggalan atas orang yang dinyatakan tidak hadir (afwezigheid).

\section{Metode Penelitian}

Rancangan ini menggunakan pendekatan yuridis normatif, yaitu jenis pendekatan yang mengkaji atau menganalisis data sekunder seperti bahan pustaka atau data sekunder yang terdiri dari bahan hukum primer, bahan hukum sekunder dan bahan hukum tersier. Bahan-bahan tersebut disusun secara sistematis, dikaji kemudian dibandingkan dan ditarik kesimpulan dalam hubungannya dengan masalah yang diteliti. 
Pendekatan penelitian yang digunakan dalam penelitian hukum ini yakni meliputi Case Approach (Pendekatan Kasus) dan Statute Approach (Pendekatan Perundang-undangan) dan Conceptual Approach (Pendekatan Konsep).

Pendekatan Konsep atau Conceptual Approach dilakukan untuk mempelajari konsep-konsep terkait dengan eksistensi kewenangan balai harta peninggalan atas orang yang dinyatakan tidak hadir (afwezigheid) yang juga menjadi fokus dalam isu hukum terkait tema penelitian.

Pendekatan Perundang-undangan atau Statute Approach ialah pendekatan dengan menggunakan legislasi dan regulasi. ${ }^{5}$ Dalam penelitian ini pendekatan dilakukan dengan menelaah peraturan perundang undangan maupun hukum positif yang berlaku di negara Indonesia khususnya yang berkaitan dengan eksistensi kewenangan balai harta peninggalan atas orang yang dinyatakan tidak hadir (afwezigheid) yang juga menjadi fokus dalam isu hukum terkait tema penelitian.

Pendekatan Kasus atau Case Approach dilakukan dengan cara kasus-kasus terkait dengan isu hukum yang sedang diteliti, dan kasus yang akan diteliti ini berupa kasus mengenai eksistensi kewenangan balai harta peninggalan atas orang yang dinyatakan tidak hadir (afwezigheid) yaitu pada Putusan Pengadilan Nomor 15/Pdt.P/2014/PN.Kdi, yang juga menjadi fokus dalam isu hukum terkait tema penelitian.

Bahan hukum yang digunakan dalam penelitian ini adalah bahan hukum primer yaitu bahan hukum yang bersifat autoritatif artinya mempunyai otoritas, terdiri dari perundang-undangan, risalah pembuatan perundang-undangan dan putusan-putusan hakim. ${ }^{6}$ Bahan hukum primer dalam karya tulis ini meliputi: 1) Kitab Undang-Undang Hukum Perdata; 2) Instruksi Untuk Balai Harta Peninggalan di Indonesia; 3) Keputusan Menteri Kehakiman RI No. M.01.PR.07.01-80 tahun 1980 tentang Organisasi dan Tata Kerja Balai Harta Peninggalan. 4) Putusan Pengadilan Negeri Nomor 15/Pdt.P/2014/PN.Kdi.

\footnotetext{
${ }^{4}$ Johnny Ibrahim, (2007), Teori dan Metodologi Penelitian Hukum Normatif, Malang: Bayumedia Publishing, Hlm. 57

${ }^{5}$ Ibid, hlm 141.
} 
Bahan hukum sekunder, yaitu buku teks karena buku teks berisi prinsip-prinsip dasarlmu hukum dan pandangan-pandangan klasik para sarjana yang mempunyai

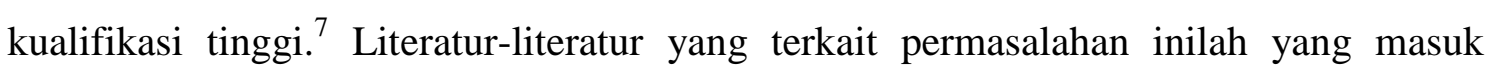
kualifikasi bahan hukum sekunder yang terkait permasalahan yang dikaji, antara lain: 1) Buku-buku hasil penelitian dan makalah; 2) Pendapat dan doktrin para sarjana; 3) Literatur yang terkait yang diperoleh dari Perpustakaan Umum Kota Malang dan Perpustakaan Pusat Universitas Kanjuruhan Malang; 4) Artikel Internet

Bahan hukum tersier, yaitu bahan hukum yang memberikan penjelasan bahan hukum primer dan sekunder terutama mengenai istilah-istilah, yang terdiri dari :1) Kamus Hukum; 2) Kamus Besar Bahasa Indonesia; 3) Kamus Terjemahan InggrisIndonesia.

\section{Hasil dan Pembahasan}

Pengertian keadaan tidak hadir adalah keadaan tidak adanya seseorang di tempat kediamannya karena berpegian atau meninggalkan tempat kediaman, baik dengan ijin atau tanpa ijin dan tidak diketahui dimana ia berada. ${ }^{8}$ Berisi substansi bahwa ketidakhadiran terjadi akibat berpisah atauterpisahnya subjek hukum itu dengan domisilinya sedangkan sepeninggalnyakekayaannya menghendaki perhatian khusus demi kepentingan subjek hukum lainyang berkepentingan dengan kekayaan milik si tak hadir itu. Terpisahnya subjek hukum tadi dengan domisilinya menurut rumusan Pasal 463 adalah karena sebabyang memang datang dari kehendaknya atau niat yang berasal atau timbul dari diri sitak hadir itu sendiri, artinya si tak hadir memiliki animus atau kehendak untuk meninggalkan domisilinya, tanpa mempersoalkan apakah niat itu timbul karena memang murni kehendaknya sendiri atau karena terpaksa oleh sebab lain, akibat dari keadaan tak hadir adalah pada penyelenggaraan kepentingan yang bersangkutan, dan pada status hukum yang bersangkutan atau anggota keluarga yang ditinggalkan. Keadaan tidak hadir dapat dibagi dalam 3 (tiga) masa, yaitu: ${ }^{9}$

\footnotetext{
${ }^{6}$ Ibid, hlm 142 .

${ }^{7}$ R. Soebekti, (1980), Pokok-Pokok Hukum Perdata, Jakarta : PT. Intermasa, cetakan ke XVI, hlm. 57.

${ }^{8}$ Tan Thong Kie, (2007), Studi Notariat Beberapa Mata Pelajaran dan Serba Serbi Praktek Notaris, Jakarta: PT.Ichtiar Baru Van Hoeve, hlm.44
} 


\section{Masa Pengambilan Tindakan Sementara}

Menurut undang-undang, seseorang adalah tidak hadir (afwezig) jika ia meninggalkan tempat tinggalnya tanpa membuat surat kuasa untuk mewakilinya dalam usaha serta kepentingannya atau dalam mengurus harta serta kepentingannya, atau jika kuasa yang diberikan tidak berlaku lagi.Tindakan sementara tersebut dimintakan kepada pengadilan negeri oleh orang yang mempunyai kepentingan harta kekayaan atau jaksa. Selanjutnya hakim akan memerintahkan kepada Balai Harta Peninggalan untuk mengurus seluruh atau sebagian harta serta kepentingan orang yang tidak hadir, kemudian BHP memiliki kewajiban untuk: ${ }^{10}$

a. Membuat pencatatan harta yang pengurursannya diserahkan kepadanya, jika perlu sebelumnya disegel dahulu (Pasal 464 jo Pasal 64 Instruksi BHP),

b. Membawa daftar pencatatan harta, surat-surat lain, dan lagi uang korban kontan serta kertas berharga ke kantor Balai Harta Peninggalan,

c. Memperhatikan segala ketentuan untuk seorang wali mengenai pengurursan harta seorang anak, kecuali diperintahkan lain oleh hakim,

d. Memberi pertanggungjawaban setiap tahun kepada jaksa dengan memperlihatkan surat-surat pengurusan dan efek-efek.

\section{Masa Ada Dugaan Hukum Mungkin Telah Meninggal}

Seseorang dapat diputuskan kemungkinan sudah meninggal jika, terdapat beberapa syarat berikut ini:

a. Seseorang terhitung tidak hadir, sejak:

1)Ia tidak hadirselama 5 tahun tanpa meninggalkan surat kuasa

2)Ia tidak hadir selama 10 tahun; surat kuasa ada, tetapi masa berlakunya sudah habis,

3)Ia tidak hadir selama 1 tahun, apabila orangnya termasuk awak atau penumpang kapal laut atau pesawar udara,

4)Ia tidak hadir selama 1 tahun, apabila orangnya hilang pada suatu peristiwa fatal yang menimpa sebuah kapal laut atau pesawat udara.

${ }^{9}$ Ibid.Hlm.45 


\section{b. Prosedur permohonan}

Permohonan persangkaan meninggal dunia tersebut diajukan oleh pihak-pihak yang berkepentingan kepada pengadilan negeri di tempat tinggal orang yang tidak hadir dan dilakukan pemanggilan sebanyak tiga kali. Panggilan tersebut dilakukan melalui harian yang ditentukan oleh hakim dan ditempelkan di pintu pengadilan negeri serta kantor walikota. Akibat persangkaan meninggal dunia adalah timbul wewenang dari orang-orang yang dianggap sebagai ahli waris untuk mengambil harta kekayaan dan meminta penyerahan barang-barang dan perincian perhitungan serta pertanggungjawaban kepada pengurus Balai Harta Peninggalan.

c. Akibat Keputusan "Mungkin Meninggal"

Para ahli waris yang diperkirakan yaitu mereka yang pada tanggal dimulainya mungkin sudah meninggal, hal ini disebut dalam keputusan pengadilan negeri yaitu ahli waris dan atau legataris (penerima hibah wasiat).

d. Hak Suami/Istri yang Ditinggal dan yang menikah dengan pencampuran harta Suami atau istri yang ditinggal dalam masa "mungkin sudah meninggal" memiliki dua pilihan yaitu meneruskan keadaan yang telah ada untuk jangka waktu maksimum 10 tahun atau segera dilakukan pembagian harta kekayaan. ${ }^{11}$

e. Keadaan "Mungkin Sudah Meninggal"

Dugaan hukum telah meninggal dapat berakhir dalam hal: ${ }^{12}$ 1) Orang yang tak hadir kembali atau ada kabar baru tentang hidupnya; 2) Si tak hadir meninggal dunia, 3) Masa pewarisan definitif dimulai.

\section{Masa Pewarisan Definitif}

Masa pewarisan definitif dimulai tiga puluh tahun setelah pernyataan persangkaan meninggal dunia tercantum dalam putusan pengadilan atau seratus tahun setelah kelahiran orang yang tidak hadir. Akibat dari dimulainya masa pewarisan definitif adalah:

\footnotetext{
${ }^{10}$ R.Soetojo Prwirohamidjojo dan Marthalena Pohan, (1991), Hukum Orang dan Keluarga (Personen en Fimilie-Recht), Surabaya: Airlangga University Press, hlm 144

${ }^{11}$ Ibid. Hlm.46
} 
a. Semua jaminan dibebaskan,

b. Para ahli waris dapat mempertahankan pembagian harta warisan sebagaimana telah dilakukan atau membuat pemisahan dan pembagian definitif,

c. Hak menerima warisan secara terbatas berhenti dan para ahli waris dapat diwajibkan menerima warisan atau menolaknya.

Berdasarakan keterangan diatas, pada asasnya yang ditunjuk sebagai pengurus (bewindvoerder) adalah Balai Harta Peninggalan. Dalam hal ini tentu BHP sebagai pengurus perlu dilengkapi dengan kewenangan-kewenangan untuk bisa mengurus dan mewakili si tak hadir mengenai seberapa besar kewenangan yang akan diberikan kepada bewindvoerder (pengurus), diserahkan sepenuhnya kepada Pengadilan. Halini tentunya disesuaikan dengan kewajiban yang disebutkan dalam Pasal 463KUHPerdata, yaitu untuk mengurus seluruh atau sebagian harta kekayaan dan kepentingan-kepentingan. Dalam hal-hal tertentu, Pengadilan bisa memberikan suatu ketetapan yang menyimpang dari asas tersebut di atas.

Pasal 463 ayat (3) KUHPerdata dengan jelas dikatakan, bahwa harta kekayaan dan kepentingan si tidak hadirtidak banyak, atas permohonan atau tuntutan seperti yang disebutkan dalam ayat (1)atau demi jabatan, Pengadilan boleh memberikan ketetapan yang menyimpangi asas tersebut di atas. Dalam Pasal 463 ayat (3) KUHPerdata dengan jelas disebutkan,yaitu dengan menunjuk bukan BHP, tetapi suami/istri, keluarga sedarah atau semenda sebagai pengurus. Untuk jelasnya perhatikan kutipan Pasal 463 ayat(3) KUHPerdata yang berbunyi:

"Sekiranya harta kekayaan dan kepentingan si yang tidak hadir itu tidakbanyak, maka atas permintaan atau tuntutan seperti tersebut di atas,ataupun dengan menyimpang dari permintaan atau tuntutan itu, karenajabatan, Pengadilan Negeri, baik dengan penetapan seperti termaksuddalam ayat (1), baik dengan penetapan lebih lanjut yang kemudian masihjuga kiranya akan diambil, berkuasa pula memerintahkan pengurusanharta kekayaan dan perwakilan kepentingan itu kepada seorang atau lebihdaripada keluarga sedarah atau semenda si yang tak hadir atau kepada istriatau suaminya, "

Salah satu contoh kasus di Pengadilan Negeri seperti pada Putusan Pengadilan Nomor 15/Pdt.P/2014/PN.Kdi.bahwa Pasal 463 ayat (3) KUHPerdata/BW, menyatakan 
Pengadilan Negeri berwenang untuk memerintahkan pengurusan harta kekayaan dan perwakilan kepentingan-kepentingan itu kepada seorang atau lebih daripada keluarga sedarah atau semenda si yang tidak hadir, atau kepada istri atau suaminya, dengan kewajiban apabila si yang tidak hadir itu pulang kembali, keluarga, suami atau istritadi harus mengembalikan kepadanya harta kekayaan itu atau harganya, setelah dikurangi dengan segala utang yang sementara itu telah dilunasinya dan tanpa hasil-hasilatau pendapatannya. Berdasarkan pertimbangan tersebut, maka Pemohon merupakan pihak yang berkepentingan selaku keluarga kandung dan salahsatu ahli waris dari Alm. K yang hendak melakukan balik nama atas warisanAlm K, dan untuk itu keberadaan SM secara hukum dibutuhkan kehadirannya dalam proses balik nama warisan tersebut, dapat membuktikan bahwa SM sejak tahun 2000 telah meninggalkan kediamannya tanpa kabar berita serta memberikan kuasa atau wakilnya kepada seseorang, demikian pula terhadap upaya panggilan umum yangdilakukan pengadilan melalui media berita (koran Radar Timur) dan pengumuman di Kantor Bupati serta pengadilan, maka SM telah memenuhi syarat untukdinyatakan ketidakhadiran (afwezigheid) secara yuridis. Berdasarkan fakta-fakta tersebut diatas, Pengadilanberpendapat bahwa permohonan Pemohon memiliki urgensi dan didasarkan atasmotivasi untuk kepentingan SM beserta Pemohon dan ahli waris yanglain, maka permohonan Pemohon tersebut cukup beralasan dan tidak bertentangan dengan Undang-undang serta peraturan hukum yang berlaku maupun nilai-nilai atau norma-norma yang hidup dalam masyarakat dan oleh karenanya permohonan dari Pemohon tersebut dapat dikabulkan

Permohonan itu lahir boleh jadi akibat permohonan yang diajukan oleh pihak yang berkepentingan dengan harta kekayaan tak hadir itu (op verzoek van belanghebbenden) sesuai dengan prosedur dan syarat-syarat yang diperlukan, yang tentu saja sebelum keputusan atau suatu beschikking dikeluarkan sangat diperlukan adanya tahapan-tahapan yang harus dilalui oleh baik organ negara di satu pihak maupun warga masyarakat di pihak lain. Dalam praktek tahapan itu didahului dengan meletakkan atau menempelkan pengumuman selama $3 \times 2$ minggu berturut-turut di papan pengumuman yang terdapat di Pengadilan Negeri setempat dan sesudah lampau waktu tersebut maka 
Pengadilan Negeri akan memutuskan untuk menerbitkan penetapan (beschikking) ketidakhadiran dimaksud.

Unsur kedekatan hubungan kekeluargaan antara si tak hadir dengan calon bewindvoerdernya memang merupakan faktor yang perlu dipertimbangkan oleh Pengadilan, hanya saja tidak ada kewajiban bagi anggota keluarga untuk menerima penunjukan sebagai pengurus (bewindvoerder).

Balai Harta Peninggalan dalam pelaksanaan tugas pokok dan fungsinya ditunjuk sebagai pengelola harta kekayaan berupa rumah atau tanah yang pemiliknya dinyatakan tidak hadir dengan Penetapan Pengadilan Negeri, Bangunan atau tanah yang dikelola oleh Balai Harta Peninggalan tersebut pada umumnya dimohonkan untuk dibeli oleh para penghuninya atau oleh mereka yang menguasai melalui Balai Harta Peninggalan (Peraturan Menteri Hukum dan Hak Asasi Manusia R1 Nomor: M.02-HT.05.10 Tahun 2005 tentang Permohonan ijin Pelaksanaan Penjualan Harta Kekayaan yang Pemiliknya dinyatakan Tidak Hadir dan Harta Peninggalan yang tidak terurus berada dalam Pengawasan BHP. ${ }^{13}$

Permohonan tersebut didasarkan oleh suatu Putusan Pengadilan Negeri sebagai dasar hukum bagi Balai Harta Peninggalan dalam melaksanakan penjualan sebagaimana yang dimohonkan oleh pemohon (Keputusan Menteri Kehakiman Republik Indonesia Nomor: M-01-HT.05.10 Tahun 1990 tentang Petunjuk Untuk Mengajukan Permohonan Izin Prinsip dan Izin Pelaksanaan Penjualan Boedel Afwezig dan Onbeheerde Nalataenschap yang berada dibawah Pengawasan dan Pengurusan Balai Harta Peninggalan.

Berdasarkan, eksistensi BHP telah dikembalikan semestinya, serta tugas maupun fungsi, berikut merupakan prosedur dari penyelesaian afwezig dari BHP: ${ }^{14}$

\footnotetext{
${ }^{13}$ http://bhpjakarta.kemenkumham.go.id/index.php?option=com content $\& v i e w=a r t i c l e \& i d=185 \&$ Itemid= 143, diakses tanggal 8 November 2016

${ }^{14} \mathrm{Ibid}$, bphjakarta.kemenmumham.go.id.
} 


\section{Jurnal Panorama Hukum}

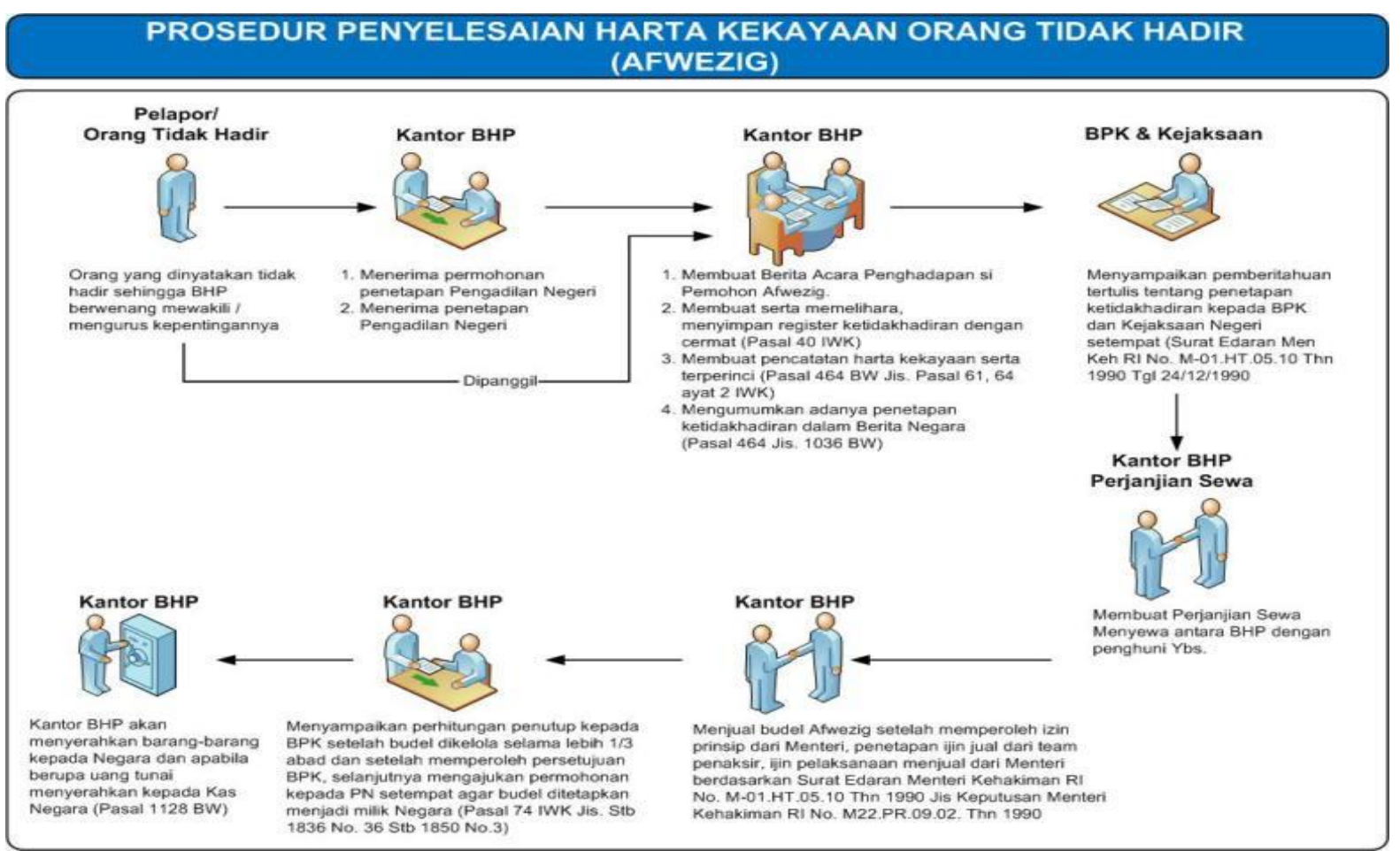

Gambar 1: SOP BHP Afwezig Kementerian Hukum dan HAM

Berdasarkan uraian di atas, yang perlu diperhatikan adalah bahwa untukpenunjukan pengurus (bewindvoerder) pada tahap ini tidak disyaratkan adanya keragu-raguan mengenai masih hidup atau sudah matinya si tak hadir, bahkan secara teoritis, tidak juga disyaratkan, bahwa keberadaan nyatanya tidak diketahui misalnya kemungkinan si tak hadir sedang sakit, sedang terhalang untuk kembali atau ditahandi tempat lain, bukankah dalam peristiwa demikian tetap ada relevansinya untuk menunjuk seorang bewindvoerder. Namun sudah tentu dalam prakteknya tidak demikian. Kalau orang tahu di mana ia (senyatanya) berada, tentunya akan dikirimkan pemberitahuan atau panggilan atas adanya kepentingan yang perlu diurus. Untuk tindakan sementara sebagaimana dimaksud Pasal 463 tersebut di atas, adalah cukup bahwa si tak hadir pada waktu meninggalkan tempat tidak telah mengatur kepentingannya, atau kuasanya untuk itu telah berakhir (habis) dan pada saat itu memang ada kebutuhan untuk pengaturan. 


\section{Kesimpulan}

Berdasarkan hasil uraian dari pembahasan penelitian ini, disimpulkan bahwamengenai tugas BHP sebagai pengampu atas orang yang dinyatakan tidak hadir (Afwezig) diatur dalam Pasal 463 KUH Perdata. Dari ketentuan pasal 463 KUH Perdata tersebut dapat kita ketahui unsur-unsur yang harus dipenuhi, seseorang dapat dinyatakan tidak hadir, yaitu:

1) Ada seseorang yang telah meninggalkan tempat tinggalnya dan tidak diketahui dimana tempat tinggalnya yang baru, demikian pula tidak dapat dibuktikan bahwa ia telah meninggal dunia;

2) Ketika meninggalkan tempat tinggalnya itu ia tidak menunjuk sseorang sebagai kuasa untuk mewakili dirinya maupun mengurus harta kekayaan dan kepentingannya. Atau kemungkinan ada kuasa tetapi kuasa itu tidak dapat dipergunakan lagi;

3) Ada harta kekayaan atau kepentingan yang mendesak harus diselesaikan;

4) Ada permohonan dari yang berkepentingan, atau tuntutan dari Kejaksaan kepada Pengadilan Negeri setempat;

5) Adanya penetapan atau keputusan Pengadilan Negeri yang menyatakan tentang ketidakhadiran tersebut.

Balai Harta Peninggalan baru ikut campur dalam hal orang tidak hadir (afwezigheid) apabila sudah ada penetapan atau putusan dari Pengadilan Negeri.

Teknis pelaksanaan yang dilakukan oleh BHP dalam mengelola harta kekayaan orang tidak hadir, yang diserahi tugas untuk mewakili diri, membela hak-hak dan pengurus harta kekayaan serta kepentingan orang tidak hadir:

1) Setelah BHP menerima turunan resmi tentang penetapan atau putusan ketidakhadiran dari Pengadilan Negeri, maka BHP segera memberitahukan kepada masyarakat melalui iklan pengumuman pada 2 surat kabar lokal dan nasional serta pada Berita Negara RI;

2) Setelah jangka waktu 14 hari sejak iklan pengumuman ternyata tidak ada masyarakat atau pihak ketiga yang berkeberatan, maka BHP segera memberitahukan hal itu kepada instansi-instansi pemerintah terkait yang ada 
hubungannya dengan diri atau harta kekayaan orang tidak hadir yaitu Pengadilan Negeri, Kantor Pertanahan, Kejaksaan, BPK, dan lain-lain;

3) Melakukan inventarisasi atas harta kekayaan orang tidak hadir (Pasal $464 \mathrm{KUH}$ Perdata) dan membuat perjanjian sewa menyewa dengan pemohon penetapan/yang berkepentingan;

4) Mewakili diri dan membela hak-hak orang yang tidak hadir itu baik di dalam maupun diluar pengadilan;

5) Apabila kepentingan boedel menghendaki, Balai Harta Peninggalan dapat melakukan penjualan atas harta kekayaan orang yang tidak hadir itu setelah terlebih dahulu mendapat ijin dari Pengadilan Negeri setempat dan Menteri Hukum dan HAM RI;

6) Apabila dalam tenggang waktu 30 tahun oarng yang dinyatakan tidak hadir tidak muncul juga, maka hasil penjualan harta kekayaan itu diserahkan/disetor ke Kas Negara, setelah terlebih dahulu diperoleh persetujuan dari Badan Pemeriksa Keuangan.

\section{Daftar Pustaka}

Johnny Ibrahim, (2007), Teori dan Metodologi Penelitian Hukum Normatif, Malang: Bayumedia Publishing.

Kantor Wilayah Kementerian Hukum dan HAM Propinsi Jawa Timur, (2016), Panduan Praktis, Balai Harta Peninggalan Surabaya Fungsi dan Tugas Pokoknya, Jakarta: Kemenkumham.

R.Soetojo Prwirohamidjojo dan Marthalena Pohan, (1991), Hukum Orang dan Keluarga (Personen en Fimilie-Recht), Surabaya: Airlangga University Press

Soebekti, R, (1980), Pokok-Pokok Hukum Perdata, Jakarta: PT. Pradnya Paramita, cetakan ke XVI.

\section{Artikel/Makalah:}

Syuhada, Analisis Hukum Terhadap Kewenangan Balai Harta Peninggalan Dalam Pengelolaan Harta Kekayaan Yang Tidak Diketahui Pemilik Dan Ahliwarisnya (Studi Di Balai Harta Peninggalan Medan),Universitas Sumatera Utara Medan, 2009. 
Peraturan Perundang-Undangan:

Kitab Undang-Undang Hukum Perdata

Instruksi Untuk Balai Harta Peninggalan di Indonesia

Keputusan Menteri Kehakiman RI No.M.01.PR.07.01-80 tahun 1980 tentang Organisasi dan Tata Kerja Balai Harta Peninggalan.

Putusan Pengadilan Negeri Nomor 15/Pdt.P/2014/PN.Kdi.

$\underline{\text { Website: }}$

www.nurhendroputranto.com.htm, "Balai Harta Peninggalan”, 2016.

http://bhpjakarta.kemenkumham.go.id/index.php?option=com_content\&view=article\&i $\underline{\mathrm{d}=185 \& \text { Itemid }=143}$, 